\title{
ИЗУЧЕНИЕ IN VIVO ДИМЕРНОГО \\ МАКРОЦИКЛИЧЕСКОГО ТАННИНА \\ (OENOTHEIN В, ДМТ) НА МЫШАХ \\ С ПЕРЕВИВАЕМЫМИ СОЛИДНЫМИ ОПУХОЛЯМИ
}

\author{
С.А. Сасов, Н.С. Сапрыкина, Л.М. Борисова, Е.Н. Бедрина, \\ Т.А. Алиева, 3.С. Шпрах, Д.В. Гусев
}

1ФГБУ «НМИЦ онкологии им. Н. Н. Блохина» Минздрава России, 115478, Россия, Москва, Каширское шоссе, 24.

DOI: 10.19163/MedChemRussia2021-2021-291

E-mail:d.gusev@ronc.ru

В настоящее время большое внимание уделяется разработке и внедрению в практику лекарственных средств на основе растительных танинов для лечения различных заболеваний человека и животных [1]. Ранее сотрудниками ФГБУ «НМИЦ онкологии им. Н. Н. Блохина» Минздрава России выявлено наличие противоопухолевых и антиангиогенных свойств у олигомерных макроциклических танинов [2, 3].

Эллаготаннин ДМТ выделен нами из соцветий Кипрея узколистного Chamerion angustifolium (L.). В рамках углубленного изучения исследовали противоопухолевую активность ДМТ in vivo методами экспериментальной химиотерапии на солидных перевиваемых опухолях мышей различного типа и патогенеза, привитых подкожно: эпидермоидной карциноме легкого Льюис LLC, меланоме B-16, аденокарциноме молочной железы Са-755, раке шейки матки РШМ-5, раке лёгкого RL-67. ДМТ в дозах 2-12,5 мг/кг вводили мышам BDF1 и CBA/Lac внутрибрюшинно ежедневно в течение 5 дней. ДMТ дозозависимо кратковременно ингибировал рост LLC (TPO (торможение роста опухоли) - 53-91\%); В16 (ТРО - 56-73\%); РШМ-5 (ТРО - 61-85\%). Наиболее сильно ДМТ ингибировал рост RL-67 (TPO 77-96\%) и Са-755 (TPO = 63100\%). Противоопухолевая активность ДМТ не зависела от типа и патогенеза перевиваемой опухоли.

Полученные результаты позволяют рекомендовать ДМТ для дальнейшего исследования с целью создания средства для лечения злокачественных заболеваний.

\section{Литература}

[1] M. Fraga-Corral et al., Foods. 2021, 10(2), 221

[2] С.А. Сасов и др., Вопросы биологической, медицинской и фармацевтической химии. 2010, 10, 24

[3] Д.А. Хоченков и др., RU2634253C1. 2016 